\title{
Pembelajaran Antargenerasi Untuk Masyarakat Berkelanjutan: Sebuah Kajian Literatur Dan Implikasi
}

\author{
Delipiter Lase ${ }^{1 *}$, Dorkas Orienti Daeli ${ }^{1}$
}

${ }^{1}$ STT Banua Niha Keriso Protestan Sundermann Nias Gunungsitoli, Indonesia

\author{
A R T I C L E IN F O \\ Article history: \\ Received 15 Agustus 2020 \\ Accepted 10 Desember \\ 2020 \\ Available online 31 \\ Desember 2020 \\ Kata Kunci: \\ Baby Boomer; Generasi X; \\ Generasi Z; Milenial; \\ Pembelajaran \\ Antargenerasi \\ Keywords: \\ Baby Boomers; Generation \\ $\mathrm{X}$; Generation Z; \\ Intergenerational Learning; \\ Millennial
}

\begin{abstract}
A B S T R A K
Artikel ini membahas tentang pembelajaran antargenerasi sebagai kendaraan sosial yang menciptakan pertukaran sumber daya yang disengaja dan yang berkelanjutan di antara generasi. Melalui kajian literatur yang diperoleh dari berbagai sumber baik cetak maupun elektronik, penulis memaparkan urgensi pembelajaran antargenerasi untuk mengembangkan modal dan kohesi sosial, membangun generasi bersama dan menjembatani kesenjangan antargenerasi. Untuk mendapatkan karakteristik yang jelas dari teori dan konsep yang dikaji, penulis menggunakan metode content analysis. Hasil dan pembahasan dititikberatkan pada upaya menggeneralisasi konsep generasi dan pengelompokannya, kesenjangan yang timbul akibat perbedaan generasi serta program yang diberi atribut sebagai pembelajaran antargenerasi. Pada bagian akhir tu;lisan, penulis memaparkan implikasi pembelajaran antargenerasi dalam tataran praktik. Bahwa dalam merancang program, penting mengidentifikasi faktor khusus keberhasilan program selain manajemen secara umum, yakni menyangkut tujuan, manfaat timbal balik, motivasi peserta, perekrutan peserta,
\end{abstract} pelibatan tenaga profesional, daya tarik konten serta tantangan lain dalam menyukseskan praktik pembelajaran antargenerasi.

\section{A B S T R A C T}

This article discusses intergenerational learning as a social vehicle that creates a deliberate and sustainable exchange of resources between generations. Through literature studies obtained from various print and electronic sources, the authors explained the urgency of intergenerational learning to develop capital and social cohesion, build a generation together, and bridge the intergenerational gap. To obtain the precise characteristics of the theories and concepts studied, the authors used content analysis. The results and discussions focused on generalizing the concept of generation and grouping, gaps arising from generation differences, and programs attributed to intergenerational learning. At the end of the paper, the author explains intergenerational learning's implications at the practice level. In designing the program, it is essential to identify specific factors of program success other than management in general, namely concerning goals, reciprocal benefits, participant motivation, recruitment of participants, professionals' involvement, content appeal, and other challenges in succeeding intergenerational learning practices. 


\section{Pendahuluan}

Tidak dapat disangkal bahwa perubahan yang luas dan cepat telah terjadi dalam masyarakat di berbagai belahan dunia, di antaranya menyangkut perubahan sosial. Perubahan sosial ini dapat meliputi perubahan struktur sosial, budaya dan interaksi. Perubahan-perubahan tersebut memengaruhi sistem sosial, nilai, sikap, dan pola perilaku individu di antara kelompok. Salah satu bentuk dari perubahan sosial yang berkembang saat ini adalah mobilitas geografis yang terus meningkat, telah menyebabkan generasi-generasi sering menjadi menjauh atau terpisah satu sama lain, khususnya orang yang lebih muda dan lebih tua. Menurut Mannion (2018), perubahan dalam demografi populasi di seluruh dunia menujukkan bahwa orang hidup lebih lama dan ini membawa perubahan dramatis dalam sifat kehidupan keluarga dan ikatan komunitas. Pemisahan ini dapat menyebabkan stereotip negatif yang tidak realistis di antara generasi dan penurunan pertukaran positif di antara mereka. Namun generasi yang terpisah ini memiliki sumber daya yang bernilai satu sama lain dan berbagi bidang yang menjadi perhatian.

Dalam KBBI, stereotip merupakan konsepsi mengenai sifat suatu golongan berdasarkan prasangka yang subjektif dan tidak tepat. Dapat dikatakan sebagai 'jalan pintas' dalam berpikir; merupakan generalisasi yang berlebihan terhadap seseorang berdasarkan sifat-sifat yang ada pada kelompoknya. Alih-alih mengembangkan modal dan kohesi sosial dalam masyarakat, generalisasi yang berlebihan justru mendorong semakin melebarnya kesenjangan antargenerasi, bahkan berpotensi melahirkan ketegangan (konflik). Kesenjangan generasi merupakan perbedaan dalam nilai dan sikap antara satu generasi dan yang lain, terutama antara orang muda dan orang tua mereka (Mendez, 2008). Perbedaan-perbedaan ini berasal dari orang yang lebih tua dan lebih muda yang tidak saling memahami karena perbedaan mereka dalam pengalaman, pendapat, kebiasaan, dan perilaku.

Bagaimana mengurangi stereotip negatif dari setiap generasi dan bagaimana dapat mengurangi kesenjangan generasi? Dalam masyarakat di mana begitu banyak generasi hidup dan bekerja bersama, diperlukan alat atau kendaraan yang memungkinkan mereka untuk saling memahami, menghormati, dan belajar dari satu sama lain. Menanggapi peningkatan kesenjangan antar generasi, Phillips et al (2010) menyoroti kolaborasi antargenerasi sebagai salah satu dasar dari konektivitas antargenerasi, yang mengarah pada pemahaman dan toleransi antar generasi. Kolaborasi dimaksud dapat berbentuk praktik, program dan/atau pembelajaran antargenerasi.

Pembelajaran dalam bentuk program antargenerasi didefinisikan sebagai kendaraan sosial yang menciptakan pertukaran sumber daya yang disengaja dan berkelanjutan di antara generasi yang lebih tua dan yang lebih muda (Kaplan et al., 2016). Pembelajaran antargenerasi memungkinkan partisipasi generasi dalam kegiatan yang mempromosikan dialog antargenerasi dan memungkinkan generasi untuk terlibat dalam perolehan keterampilan, nilai, dan pengetahuan.

Artikel ini merupakan hasil kajian literatur, yang secara beruntun membahas tentang definisi generasi dan pengelompokan, stereotip dan kesenjangan yang ditimbulkannya, serta urgensi pembelajaran antargenerasi baik dalam tataran konseptual maupun praktik. Dan, pada akhirnya tulisan ini bertujuan untuk menggeneralisasi konsep atau teori yang berhubungan dengan pembelajaran antargenerasi, yang mana pada bagian akhir tulisan penulis memaparkan implikasi pembahasan berupa gagasan penulis tentang pembelajaran antargenerasi dalam tataran praktik.

\section{Metode}

Untuk mengembangkan konsep yang relevan dengan topik, penulis melakukan tinjauan literatur yang diperoleh dari berbagai sumber: buku dan jurnal ilmiah, laporan penelitian, esai ilmiah, tesis dan disertasi, ensiklopedi dan sumber cetak dan elektronik lainnya. Lebih lanjut, bahwa untuk mendapatkan karakteristik yang jelas dari wacana berupa teori dan konsep yang dikaji, penulis menggunakan metode content analysis, yakni suatu teknik penelitian untuk membuat inferensi yang dapat direplikasi dan sahih datanya dengan memerhatikan konteksnya (Krippendorff, 2004; Kriyantono, 2012). 


\section{Pembahasan \\ Generasi dan Perbedaan Generasi}

Istilah generasi atau juga dikenal dengan istilah angkatan atau kelompok umur sering digunakan oleh para peneliti untuk menggambarkan sikap publik tentang isu-isu utama (sosial budaya, politik, dan ekonomi) berdasarkan kelompok demografis (Dimock, 2019). Menurut Mannheim, generasi adalah suatu konstruksi sosial dimana di dalamnya terdapat sekelompok orang yang memiliki kesamaan umur dan pengalaman historis yang sama (Mannheim, 1952; Meja \& Kettler, 2017). Lebih lanjut dijelaskan bahwa individu yang menjadi bagian dari satu generasi, adalah mereka yang memiliki kesamaan tahun lahir dalam rentang waktu 20 tahun dan berada dalam dimensi sosial dan dimensi sejarah yang sama. Definisi lebih spesifik dikembangkan oleh Ryder yang adalah agregat dari sekelompok individu yang mengalami peristiwa-peristiwa yang sama dalam kurun waktu yang sama pula (Ryder, 1965).

Seiring bergesernya waktu, definisi generasi juga mengalami perkembangan, salah satu di antaranya adalah definisi menurut Kupperschmidt (2000) dalam Yanuar (2016) yakni sekelompok individu yang mengidentifikasi kelompoknya berdasarkan kesamaan tahun kelahiran, umur, lokasi, dan kejadian-kejadian dalam kehidupan kelompok individu tersebut yang memiliki pengaruh signifikan dalam fase pertumbuhan mereka.

Pada tahun 2000 Howe dan Strauss memperkenalkan teori tentang perbedaan generasi, mereka mengelompokkan generasi berdasarkan kesamaan rentang waktu kelahiran dan kesamaan kejadian-kejadian historis (Howe \& Strauss, 2000) Para peneliti lainnya melakukan hal yang sama dengan label yang berbeda-beda, tetapi secara umum memiliki makna yang sama. Beberapa hasil penelitian tentang pengelompokkan generasi, dapat dilihat pada tabel berikut.

Tabel 1

\section{Pengelompokkan Generasi}

\begin{tabular}{lcccc}
\hline \multicolumn{1}{c}{ Sumber } & \multicolumn{4}{c}{ Label } \\
\hline Tapscott (1998) & Baby Boom & Generation X & Digital Generation & - \\
& $1946-1964$ & $1965-1975$ & $1976-2000$ & - \\
\hline Howe \& Strauss & Boom Generation & $13^{\text {th }}$ Generation & Millenial & - \\
(2000) & $1943-1960$ & $1962-1981$ & $1982-2000$ & - \\
\hline Lancaster \& & Baby Boomers & Gen-Xers & Nexters & - \\
Stillman (2002) & $1943-1960$ & $1960-1980$ & $1980-1999$ & - \\
\hline Martin \& Tulgan & Baby Boomers & Generation X & Millenials & \\
(2002) & $1946-1964$ & $1965-1977$ & $1981-1999$ & Post Milleniak \\
\hline Oblinger \& & Baby Boomers & Gen-Xers & Gen Y/NetGen & 1995-present \\
Oblinger (2005) & $1947-1964$ & $1965-1980$ & $1981-1995$ & Generation Z \\
\hline \hline Pew Research & Boomers & Generation X & Millenials & Genen \\
Centre (2019) & $1946-1964$ & $1965-1980$ & $1981-1996$ & $1997-2012$ \\
\hline
\end{tabular}

Sumber: Yanuar (2016) dan Dimock (2019)

\section{Pengelompokkan Generasi}

Untuk melihat bagaimana generasi ini dikelompokkan, para ahli menggunakan beberapa teori. Di antaranya, pertama, berdasarkan teori sosiologis (Mannheim, 1970) dalam (Urick et al., 2017), satu generasi dianggap sebagai ilusi di mana "identitas lokasi, merangkul 'kelompok umur' terkait dalam proses sosial-historis," menciptakan "gestalt". Masyarakat dan anggota generasi tertentu mempersatukan kesatuan dengan gestalt generasi, dan percaya bahwa karakteristik kolektif dari generasi menggeneralisasi semua individu di dalamnya. Dalam pandangan ini, anggota dari setiap generasi (secara kolektif) menghadapi beberapa peristiwa atau peristiwa di awal kehidupan mereka yang akhirnya membentuk pemahaman mereka tentang dunia dan 
membedakan mereka dari generasi lain (Joshi et al., 2011). Pengalaman bersama tentang peristiwa-peristiwa yang terjadi selama tahun-tahun pembentukan ini menetapkan nilai-nilai, motivator, dan karakteristik generasi, sehingga membatasi di mana generasi dimulai dan berakhir (Schuman \& Scott, 1989).

Kedua, definisi silsilah generasi mewakili generasi yang terkait dengan garis keturunan, mirip dengan konsep garis keturunan dalam keluarga, di mana generasi seseorang ditentukan oleh di mana ia cocok berkaitan dengan suksesi keluarga (Joshi et al., 2011). Ketiga, generasi didefinisikan menurut ritus perikop bersama. Dalam pandangan ini, individu pada tahap kehidupan tertentu mengalami ritus perikop yang berkontribusi pada kedewasaan mereka (Joshi et al., 2011). Keempat, generasi didefinisikan berdasarkan usia biologis atau tahun kelahiran. Pendekatan ini mendapat perhatian paling besar (mis., Kupperschmidt, 2006; Twenge, 2010). Pengelompokan generasi yang populer (dari yang termuda ke yang tertua) meliputi generasi $Y$ (juga dikenal sebagai milenium), generasi X, baby boomer, dan generasi veteran, semua kategori berdasarkan tahun kelahiran (Smola et al., 2002).

Terakhir, penelitian terbaru telah memperluas definisi generasi dan mengadopsi gagasan bahwa generasi seseorang dapat berfungsi sebagai identitas sosial yang penting di mana individu menarik diri untuk membandingkan diri mereka dengan orang lain (Urick \& Hollensbe, 2014). Dalam membuat perbandingan ini, perbedaan yang dirasakan dengan orang lain diidentifikasi, dibuat dalam kelompok dan luar kelompok. Gagasan ini didukung secara empiris oleh Finkelstein et al., (2001) bahwa orang mendefinisikan diri mereka sendiri berdasarkan generasi mereka dan mempertahankan identitas ini dari waktu ke waktu.

Dari teori-teori tersebut di atas, menurut (Parry \& Urwin, 2011) pengelompokkan generasi berdasarkan teori sosiologis lebih banyak dipakai sebagai dasar dalam studi maupun penelitian tentang perbedaan generasi. Generasi terbentuk lebih disebabkan karena kejadian atau even yang bersejarah dibanding dengan tahun kelahiran. Beberapa penelitian lainnya, juga berfokus pada penentuan sampel berdasarkan pengelompokan usia berdasarkan empat label generasi populer ini yakni Baby Boomer, Generasi X Generasi Y dan Generasi Z (Lyons \& Kuron, 2014; Parry \& Urwin, 2011). Meskipun muncul dari pers populer bahwa perbedaan generasi ada berdasarkan pengelompokan ini, namun meta-analisis tentang perbedaan generasi dalam sikap yang berhubungan dengan pekerjaan (seperti kepuasan kerja, komitmen, dan keinginan berpindah), Costanza et al., (2012) menemukan sedikit perbedaan signifikan di antara anggota dari empat kategori generasi umum ini.

\section{Karakteristik Generasi}

Walmsley (2011) mencatat bahwa anggota generasi Baby Boomers lahir ketika telepon dan televisi merupakan kontribusi teknologi utama bagi rumah tangga. Prensky (2001) menyebut generasi ini "digital immigrants" karena "digital" adalah bahasa kedua mereka dan mereka perlu belajar bahasa ini untuk berkomunikasi dengan "digital natives".

Baby Boomer sangat kompetitif, karena jumlah mereka yang besar dan mereka unggul, terutama dalam situasi kerja. Mereka merasa, bagaimanapun, untuk terus unggul, karena tekanan karir dari generasi muda dan kurangnya pengetahuan teknologi Glass (2007, p. 100). Baby Boomers dipandang sebagai seorang yang loyal, berkomitmen, dan dapat diandalkan, tetapi mereka juga mengharapkan kesetiaan dari orang lain di sekitar mereka - di tempat kerja sebagai majikan dan karyawan, di rumah sebagai orang tua dan di sekolah sebagai guru. Mereka menghormati hierarki dan otoritas dan mengharapkan rasa hormat dari orang lain, terutama dari generasi muda (Helyer \& Lee, 2012, p. 568; Heng \& Yazdanifard, 2013, p. 837). Generasi ini memiliki etos kerja yang kuat. Karier mereka sangat penting bagi mereka dan mereka percaya pada stabilitas, kadang-kadang tetap dalam satu karir dan menggunakan peluang dalam karir yang satu ini selama masa hidup mereka (Helyer \& Lee, 2012, p. 568).

Baby Boomers sering kurang menghargai keterampilan baru dari Generasi Y. Mereka terbiasa belajar 'langkah demi langkah, satu hal pada satu waktu, secara individu, dan di atas semua, dengan serius, berbeda dengan multi-tasking, multi-media, cara belajar yang 
menyenangkan diadopsi oleh Generasi Y (Prensky, 2001). Baby Boomers lebih suka otonomi dan etos kerja yang berbeda dari rasa kolaborasi Generasi Y (Helyer \& Lee, 2012, hlm. 568).

Baby Boomers berkomunikasi sebagian besar menggunakan komunikasi tatap muka, percakapan telepon, dan email. Mereka jarang akan menggunakan blog, wiki, situs jejaring sosial dan SMS atau pesan instan dalam situasi yang lebih formal, seperti dalam konteks pekerjaan (Heng \& Yazdanifard, 2013, p. 838). Mereka mengandalkan komunikasi tatap muka di mana bahasa tubuh dan isyarat non-verbal penting (Walmsley, 2011, p. 25). Generasi yang lebih tua semakin banyak menggunakan komputer sebagai media komunikasi, tetapi sebagian besar melalui email atau pesan singkat di ponsel. Namun, secara bertahap, mereka bergerak ke arah penggunaan media sosial dan digital lainnya (Turnbull, 2010, p. 7), tetapi banyak dari anggota yang lebih tua dari generasi ini masih merasa tidak nyaman dengan komunikasi dengan media komputer (Venter, 2017, p. 500).

Generasi X disebut sebagai Lost Generation yang lahir antara tahun 1966 - 1976 (Tay, 2011). Generasi X belajar dari para tetua mereka bahwa mengikuti peraturan dan peraturan perusahaan kemungkinan besar tidak akan mengamankan pekerjaan mereka (Gursoy et al., 2008). Kohort generasi ini menempatkan pentingnya menjaga keseimbangan kerja-hidup dan terus mencari keseimbangan antara keluarga, kehidupan, dan pekerjaan (Gursoy et al., 2008; Williams et al., 2010). Sejumlah penelitian telah menemukan generasi $X$ memiliki beberapa karakteristik penting. Santos \& Cox, (2000) menemukan generasi X lebih memilih organisasi yang memberi mereka jadwal kerja yang fleksibel, otonomi tinggi, pekerjaan yang menarik namun menantang, dan peluang berkelanjutan untuk pertumbuhan profesional. Oleh karena itu, mereka memperlakukan pekerjaan yang didelegasikan kepada mereka sebagai tugas dan lebih suka melakukannya sendiri (Greenwood et al., 2010).

Generasi X sangat bergantung pada keterampilan mereka sendiri dan percaya pada penilaian mereka sendiri untuk melakukan tugas mereka secara mandiri (Sayers, 2007). Gursoy et al., (2008) memandang karyawan Gen X sebagai karyawan yang lebih suka bekerja dengan cerdas, mereka akan selalu mencari cara mereka sendiri untuk melaksanakan tugas mereka daripada sekadar mengikuti apa yang biasanya dilakukan oleh senior mereka. Dengan bantuan sifat khas mereka dalam literasi teknologi, mereka menunjukkan dukungan tinggi dalam lingkungan kerja yang diisi oleh teknologi tinggi yang memungkinkan mereka untuk melakukan tugas mereka secara mandiri. Selain itu, mereka lebih fokus pada pengembangan karir sendiri (Santos \& Cox, 2000) dan dimotivasi oleh keinginan untuk meningkatkan keterampilan profesional mereka untuk meningkatkan pemasaran terhadap prospek karir masa depan (Gursoy et al., 2008; Sayers, 2007). Mereka memiliki toleransi yang rendah dalam mengantri giliran mereka untuk promosi dan menantikan pengakuan langsung dan penghargaan mereka setiap kali mereka melakukan pekerjaan yang baik.

Generasi Y lahir antara 1980 dan kurang lebih 2000 (Hartman \& McCambridge, 2011, p. 22; Liu et al., 2012, p. 697). Beberapa penulis menyebutnya generasi milenium (Howe \& Strauss, 2000). Penulis lain menggambarkan generasi ini menggunakan konsep seperti digital natives (Prensky, 2001), the net generation (Bossert, 1999), the web generation (Hartmann, 2003) atau the Google generation (Helsper \& Eynon, 2010). Anggota Generasi Y adalah penduduk asli digital karena mereka tumbuh dengan mengalami teknologi digital dan telah mengetahuinya sepanjang hidup mereka. Prensky (2001) menciptakan konsep 'digital natives' karena generasi ini adalah 'penutur asli bahasa digital komputer, video game, dan internet'. Generasi ini berusia 20 tahun dan anggota yang lebih tua menggunakan kombinasi komunikasi tatap muka dan komunikasi yang dimediasi komputer, sementara anggota yang lebih muda menggunakan terutama teknologi elektronik dan digital untuk komunikasi antarpribadi. Mereka merangkul teknologi baru dan inovatif dan sering disebut 'they savvy multi-tasker' (Eckleberry-Hunt \& Tucciarone, 2011, p. 458).

Tekno-sentrisitas generasi ini menekankan pada individu, tetapi mereka juga membutuhkan interaksi kelompok, terutama mengingat kebutuhan mereka akan umpan balik yang konstan. Generasi Y tumbuh dengan orang tua yang terlalu protektif yang terus-menerus meyakinkan mereka betapa istimewanya mereka. Dengan demikian dukungan dari orang lain dalam kehidupan mereka sangat penting bagi mereka (Eckleberry-Hunt \& Tucciarone, 2011, p. 
458). Karena orang tua dan guru memberikan generasi ini, semua penegasan yang mereka butuhkan untuk sukses, mereka sering memiliki perasaan berhak dan keinginan untuk pengakuan atas prestasi mereka. Mereka akan menantang orang yang berwenang jika mereka pikir mereka dapat memberikan kontribusi yang berharga dan tidak mendapatkan pengakuan yang mereka anggap layak mereka dapatkan. Di sisi lain, bagaimanapun, mereka menginginkan keseimbangan antara pekerjaan atau studi mereka dan kehidupan pribadi serta tidak sefokus Baby Boomers pada satu tujuan hidup (Reilly, 2006, p. 4).

Generasi Z memiliki atribut "net generastion" karena era digital yang sangat maju, tempat mereka dilahirkan. Mereka juga dicirikan sebagai "Facebook-generation", "digital native" atau kadang-kadang "iGeneration" (Tari, 2011) dalam (Bencsik et al., 2016). Norma-norma generasi Z berbeda dari norma-norma generasi sebelumnya. Kata-kata, slang (ragam bahasa musiman), dan ekspresi yang digunakan oleh generasi $\mathrm{Z}$ cukup aneh bagi orang tua mereka dan kedua belah pihak terkadang terpisah. Generasi Z dilahirkan di dunia teknologi dan mereka merasa nyaman di dunia itu, hal ini sangat penting bagi mereka dan menginginkan lingkungan tersebut mengelilingi mereka. Mereka selalu online di perangkat teknis apa pun secara virtual, tanpa berhenti. Bentuk sosialisasi lain sangat sulit bagi mereka. Dibandingkan dengan generasi Y, generasi Z tidak menyadari konsep perjuangan. Mereka praktis, lebih pintar daripada bijak dan mereka suka memimpin karena mereka berani. Mereka lebih tidak sabar dan lebih gesit dari pendahulunya dan mereka mencari tantangan dan impuls baru secara terus menerus. Mereka tidak takut akan perubahan terus-menerus dan karena dunia internet mereka memiliki banyak informasi, tetapi hanya sampai batas tertentu. Untuk mengatasi masalah, mereka mencoba mencari solusi di internet (Tari, 2011).

Dari karakteristik generasi di atas, tampak bahwa setiap generasi memiliki value (nilai), view (cara pandang), dan pola pikir tentang banyak hal menyangkut aspek kehidupan. Perbedaanperbedaan mendasar ini berkontribusi pada pembentukan sikap, perilaku, opini, gaya hidup dan relasi baik secara individu maupun dalam konteks sosial kemasyarakatan. Pertanyaan kemudian adalah apakah perbedaan generasi ini menjadi masalah, sesuatu yang dikuatirkan atau barangkali menjadi sebuah ancaman dalam membangun dan mengembangkan modal dan kohesi sosial?

Bertolak dari berbagai literatur mengenai generasi, diperoleh kesimpulan bahwa generasi adalah atribut atau label (konstruksi sosial) dan bukan penyebab. Meskipun demikian, mencermati cara pandang, nilai, sikap, relasional serta karakteristik yang dimiliki oleh tiap-tiap generasi yang terbentuk akibat perubahan stuktur sosial, sejarah dan perkembangan teknologi dan ilmu pengetahuan, tanpa disadari telah melahirkan stereotip generasi dan mendorong semakin melebarnya kesenjangan antargenerasi dalam masyarakat multigenerasi.

\section{Kesenjangan Angtagenerasi}

Kesenjangan generasi sering digambarkan sebagai perbedaan pemikiran, antara orangorang dari dua generasi yang berbeda. Ini adalah fenomena universal, dan perbedaan persepsi ini dapat terjadi antara siapa saja seperti orang tua dan keturunannya; guru dan murid mereka; majikan dan bawahannya. Pemikiran ini sejalan dengan definisi generation gap yang dinyatakan oleh Mendez (2008) yakni " a difference in values and attitudes between one generation and another, especially between young people and their parents. These differences stem from older and younger people not understanding each other because of their differences in experiences, opinions, habits, and behavior".

Meskipun tidak ada definisi universal tentang kesenjangan generasi, karena kesenjangan generasi adalah konstruksi sosial, yang berarti bahwa konsepsi dipengaruhi oleh nilai-nilai kompleks, norma, sikap, sejarah, hubungan sosial dan lainnya serta interaksi yang terikat waktu dan budaya, dan memiliki makna dan interpretasi yang berbeda di berbagai masyarakat dan konteks (Berger \& Luckmann, 1991). Namun sosiolog di negara-negara barat mendefinisikan kesenjangan generasi sebagai perbedaan gaya hidup antara satu generasi dan yang lain, dan biasanya antara generasi muda dan generasi yang lebih tua (Stepp, 2007). Ini menunjukkan bahwa setiap generasi memiliki pola pikir bersama tentang keluarga, gaya hidup, peran gender, 
pernikahan, politik, profesi, kehidupan sosial, agama, gaya hidup, dan masa depan (Howe \& Strauss, 2007, p. 60).

Untuk pertama kalinya kesenjangan antar generasi dirumuskan oleh sosiolog Hongaria Karl Mannheim pada tahun 1923. Teori ini berpendapat bahwa perubahan lingkungan (sosial, budaya politik, teknologi, ilmu pengetahuan, dsb) membuat satu generasi berbeda dengan generasi lainnya (Mannheim, 1952, pp. 163-195; Meja \& Kettler, 2017). Lebih lanjut, teori-teori sosiologi lain tentang kesenjangan generasi mulai berkembang pada tahun 1960-an, ketika generasi muda (yang kemudian dikenal dengan Baby Boomers) tampaknya menentang segala sesuatu yang sebelumnya orang tua mereka yakini dalam hal musik, nilai-nilai, pandangan pemerintah dan politik. Sosiolog sekarang menyebut "kesenjangan generasi" sebagai "pemisahan usia institusional" (institutional age segregation). Yakni, ketika salah satu dari kelompok umur ini terlibat dalam aktivitas utamanya, anggota individu secara fisik terisolasi dari orang-orang dari generasi lain, dengan sedikit interaksi di seluruh batasan usia kecuali pada tingkat keluarga inti (Subramanian, 2017).

Apakah perbedaan generasi adalah fakta atau fiksi? Perbedaan generasi dalam konteks dunia kerja (workplace) termasuk pendidikan, pada prinsipnya tidak memiliki kontribusi yang signifikan terkait dengan hasil (output) organisasi. Namun di sisi lain, kita juga dapat dengan mudah mendapatkan streotip, label atau atribut yang diberikan kepada generasi tertentu oleh generasi lainnya baik melalui media atau pers populer bahkan dari hasil penelitian. Majalah Time 2013 mengeluarkan sebuah edisi mengenai Generasi Millennial dengan cover bertuliskan "Millennials adalah pemalas, narsistis yang masih tinggal dengan orangtuanya." Generasi Lembek dan Kaum Rebahan (Detik, 2019); generasi millenial menyandang citra pemalas, egois, sombong, penggila teknologi, dan materialistis (Tirto, 2017). Sementara itu, persepsi positif terhadap generasi baby boomer tak semuanya benar. Di Indonesia, generasi ini dilabel dengan generasi yang paling banyak tersangkut masalah korupsi. Di tataran dunia, generasi baby boomer dipandang sebagai generasi yang mengeksploitasi dan menghabiskan minyak dan gas bumi, mewariskan pemanasan global dan perubahan iklim bagi generasi-generasi selanjutnya. "OK Boomer" yang viral di tahun 2019 (New York Times, 2019) muncul sebagai ungkapan statistik generasi Z dan Millenial untuk merespon sikap generasi baby bommer, yang menurut mereka gemar menggurui, kurang relevan dengan zaman sekarang.

Perbedaan generasi yang paling banyak menyita perhatian adalah perbedaan generasi di tempat kerja atau organisasi. Namun dalam tulisan ini, penulis tidak membahasnya secara luas. Kecuali, bahwa berbagai penelitian menyangkut perbedaan generasi di tempat kerja seperti pengaruh perbedaan generasi pada proses kerja dan hasil; konflik dan potensi antargenerasi di tempat kerja, hasilnya "tidak ada" dan negatif". Akumulasi bukti menunjukkan bahwa tidak ada perbedaan generasi yang cukup besar dalam sikap dan nilai yang terkait dengan pekerjaan, seperti kepuasan kerja, komitmen organisasi, niat berpindah, atau etos kerja (Costanza et al., 2012; Zabel et al., 2017). Juga tidak ada dukungan empiris untuk gagasan populer bahwa pengawas harus menyesuaikan gaya kepemimpinan mereka dengan generasi yang berbeda (Rudolph et al., 2019). Setiap perbedaan kecil yang tampaknya ada lebih mungkin dikaitkan dengan sesuatu selain generasi dan sepenuhnya dikacaukan dengan sumber varian lain, yaitu efek usia atau periode.

Tinjauan literatur lainnya tentang perbedaan generasi di tempat kerja menyimpulkan bahwa "bukti sampai saat ini retak, bertentangan dan penuh dengan inkonsistensi metodologis yang membuat generalisasi menjadi sulit" (Lyons \& Kuron, 2014, p. 139). Oleh karena itu, penting untuk menekankan bahwa kebijakan ekonomi, tenaga kerja, dan organisasi tidak boleh didasarkan pada klaim yang tidak dapat dipertahankan tentang perbedaan generasi yang ditemukan dalam literatur.

\section{Pembelajaran Antargenerasi}

Dalam masyarakat di mana begitu banyak generasi hidup dan bekerja bersama, diperlukan alat atau kendaraan yang memungkinkan mereka untuk saling memahami, menghormati, dan belajar dari satu sama lain. Apa yang terlintas dalam pikiran kita ketika seseorang bertanya 
tentang generasi tua dan muda? Mungkin kita akan memikirkan stereotip dari setiap generasi atau bagaimana generasi berbeda satu sama lain. Seringkali stereotip itu akan menjadi sesuatu yang negatif daripada positif. Pertanyaan kemudian adalah, bagaimana kita dapat mencoba mengurangi stereotip negatif dari setiap generasi dan bagaimana dapat mengurangi kesenjangan generasi? Kebanyakan orang tahu tentang apa konsep kesenjangan generasi dan bagaimana hal itu semakin berkembang di masyarakat. Hari demi hari, kita dapat melihat bagaimana kesalahpahaman yang semakin membesar terdapat di semua tingkatan antara generasi muda dan generasi tua. Namun, belum terlambat untuk memperbaikinya dan menyatukan generasigenerasi itu. Mencapai ini bisa bermanfaat tidak hanya bagi masyarakat tetapi juga secara ekonomi.

Sebuah laporan yang diterbitkan oleh EUROPOP (2015) melaporkan bahwa struktur demografis telah berubah dan proyeksi populasi jangka panjang menunjukkan peningkatan pangsa populasi yang lebih tua di negara maju (Eurostat, 2019). Penuaan populasi ini memiliki dampak kuat pada hubungan antar generasi. Sikap terhadap penuaan dan orang tua terbentuk pada usia dini (Kornadt \& Rothermund, 2011), anak-anak sudah memiliki sikap negatif dan stereotip terhadap generasi yang lebih tua (Gilbert \& Ricketts, 2008).

Dalam masyarakat industri, modernisasi dan perkembangan teknologi menyebabkan perubahan peran orang tua dan meningkatkan keterasingan generasi (Imogen Lyons, 2013). Setelah pemutusan hubungan kerja, orang-orang lebih tua dicap sebagai orang-orang yang mengurangi standar materi dan mengurangi kontak sosial. Ada pandangan yang berlaku bahwa lansia terutama merupakan beban sosial, dan mereka sering mengalami isolasi, yang merupakan sumber dari berbagai konflik dan penciptaan stereotip negatif (Cotten et al., 2013). Fivush et al., (2011) menekankan bahwa kualitas hidup dan masa depan generasi berikutnya bergantung pada kerja sama dan koeksistensi antar generasi. Menanggapi peningkatan kesenjangan antar generasi, para ahli (Phillips et al., 2010) menyoroti kolaborasi antargenerasi sebagai salah satu dasar dari konektivitas antargenerasi, yang mengarah pada pemahaman dan toleransi antar generasi.

Organisasi internasional urusan pendidikan, keilmuan, dan kebudayaan (UNESCO) mendefinisikan pembelajaran antargenerasi sebagai "kendaraan sosial yang menciptakan tujuan dan pertukaran sumber daya yang sedang berlangsung dan belajar di antara generasi yang lebih tua dan yang lebih muda" (Aemmi \& Moonaghi, 2017). Pembelajaran antargenerasi merupakan mekanisme yang mendorong interaksi antara generasi yang lebih tua dan yang lebih muda melalui partisipasi dalam kegiatan yang terorganisir. Salah satu kegiatannya adalah untuk mengenalkan murid sekolah dasar dengan profesi yang berbeda dalam konteks pembelajaran antargenerasi (Berčan \& Ovsenik, 2019).

Pembelajaran dalam bentuk program antar generasi didefinisikan sebagai kendaraan sosial yang menciptakan pertukaran sumber daya yang disengaja dan berkelanjutan di antara generasi yang lebih tua dan yang lebih muda (Kaplan et al., 2016). Pembelajaran antargenerasi memungkinkan partisipasi generasi dalam kegiatan yang mempromosikan dialog antargenerasi dan memungkinkan generasi untuk terlibat dalam perolehan keterampilan, nilai, dan pengetahuan. Ini adalah salah satu cara untuk mengatasi perubahan demografis dan membuat kontribusi penting untuk pengembangan modal sosial dan kohesi sosial dalam masyarakat lanjut usia (Berčan \& Ovsenik, 2019). Definisi lainnya datang dari The European Network for Intergenerational Learning (ENIL), yakni "a learning partnership based on reciprocity and mutuality involving people of different ages where the generations work together to gain skills, values and knowledge" (Kernan \& Cortellesi, 2019).

Berangkat dari pandangan para ahli di atas, maka dapat disimpulkan bahwa pembelajaran antargenerasi merupakan cara orang dari segala usia dapat belajar bersama dan dari satu sama lain, serta menjadi bagian penting dari pembelajaran seumur hidup, di mana generasi bekerja bersama untuk memperoleh keterampilan, nilai, dan pengetahuan. Di luar transfer pengetahuan, pembelajaran antargenerasi dapat memupuk hubungan pembelajaran timbal balik antara generasi yang berbeda dan membantu mengembangkan modal sosial dan kohesi sosial dalam masyarakat kita yang sudah lanjut usia. Dengan demikian, pembelajaran antargenerasi menjadi salah satu cara untuk mengatasi perubahan demografis dengan tujuan untuk meningkatkan solidaritas antar generasi. 
Mengapa akhirnya pembelajaran antargenerasi menjadi kebutuhan? Banyak perubahan dalam masyarakat, seperti mobilitas geografis yang meningkat telah menyebabkan generasigenerasi sering menjadi menjauh atau terpisah satu sama lain, khususnya orang yang lebih muda dan lebih tua. Pemisahan ini dapat menyebabkan stereotip negatif yang tidak realistis di antara generasi dan penurunan pertukaran positif di antara mereka. Namun generasi yang terpisah ini memiliki sumber daya yang bernilai satu sama lain dan berbagi bidang yang menjadi perhatian misalnya, generasi yang lebih muda dan lebih tua sering terpinggirkan dalam pengambilan keputusan yang secara langsung mempengaruhi kehidupan mereka.

Pembelajaran antargenerasi sebagai program berbagi atau bertukar pembelajaran dan sumber daya antara generasi yang lebih tua dan yang lebih muda, bertujuan untuk mempromosikan rasa hormat, inklusi sosial dan pemahaman yang lebih besar antar generasi. Menurut Rabušicová \& Novotný (2016), setidak-tidaknya ada tiga alasan mengapa pembelajaran antargenerasi semakin menarik bagi para peneliti, politisi, pendidik, dan pengusaha yang mulai menghargai manfaatnya bagi individu maupun bagi masyarakat luas yakni pertama, perkembangan demografis saat ini membawa generasi yang lebih tua jumlahnya terus bertambah dan harapan hidup mereka terus meningkat. Pertemuan antar generasi memberikan kesempatan untuk berbagi pengetahuan dan keterampilan dan untuk membangun rasa saling menghormati dan kerja sama yang erat. Aspek positifnya adalah kesempatan untuk belajar dan terinspirasi oleh pengalaman generasi lain ketika berhadapan dengan masalah.

Kedua, terkait dengan kekhawatiran. Masyarakat multi-generasi adalah masalah sensitif; hubungan antar generasi berpotensi melibatkan konflik dan dapat diartikan sebagai perjuangan untuk sumber daya, ruang, dan perhatian. Selain itu, pada saat yang sama, ada kekhawatiran tentang kurangnya pemahaman di antara generasi, kontak yang terbatas karena perbedaan gaya hidup, atau keterasingan timbal balik. Situasi hidup bersama secara alami dari generasi ke generasi dalam keluarga adalah gambaran dimana perlunya upaya merancang program antar generasi yang bertujuan untuk mengkompensasi perkembangan ini. Ketiga, terkait dengan potensi pertemuan antargenerasi. Pembelajaran antargenerasi memiliki manfaat potensial untuk pertumbuhan pribadi, membangun modal sosial, dan mempertahankan koherensi sosial. Pembelajaran antargenerasi memainkan peran kunci dalam membuka potensi ini.

Dalam pembelajaran antargenerasi, generasi yang lebih tua mendapat kesempatan untuk mentransfer pengetahuan, pengalaman, dan membaginya dengan generasi muda, yang mengarah pada kualitas hidup yang lebih tinggi bahkan pada tahap ketiga kehidupan. Generasi muda dapat memperoleh informasi yang konkret dan berguna tentang profesi secara langsung dan juga belajar tentang penuaan dan toleransi sosial (Berčan \& Ovsenik, 2019).

Menurut Henkin \& Butts (2012), pekerjaan antargenerasi memiliki potensi untuk menyatukan usia, ras dan budaya untuk mendukung kebijakan dan praktik yang membantu semua individu menjadi warga negara produktif yang menggunakan keterampilan dan bakat mereka untuk berkontribusi pada komunitas tempat mereka tinggal. Ini dapat mempromosikan nilai-nilai yang menumbuhkan rasa saling ketergantungan, mempromosikan kontribusi seumur hidup, dan meningkatkan pengakuan nasib bersama. Dalam konteks organisasi, pembelajaran antargenerasi adalah cara alami untuk mengatur pembelajaran di tempat kerja untuk merangsang penggunaan kapasitas pekerja yang lebih tua secara efektif (Ropes, 2013). Ini dapat memberikan manajer ide tentang mengatur pembelajaran antargenerasi sebagai strategi untuk berurusan dengan populasi pekerja yang menua.

Dunia modern ditandai oleh perubahan mendasar dalam paradigma sosial. Perkembangan teknologi digital dan ruang virtual telah menciptakan kondisi kehidupan baru di mana ada "perubahan peran" yakni generasi yang lebih tua membutuhkan bantuan orang muda dalam memperoleh realitas baru. Temuan studi yang dilakukan oleh Darinskaia \& Moskvicheva (2019) menunjukkan bahwa orang tua dan remaja optimis tentang prospek interaksi antargenerasi di bidang pendidikan digital. Lebih lanjut dikatakan hambatan tertentu dalam persepsi dan pemahaman timbal balik dapat diatasi, khususnya, dalam program pelatihan yang diselenggarakan secara khusus. Dengan demikian, pendidikan antargenerasi dapat dianggap sebagai salah satu sumber penting sosialisasi digital pada orang tua. 
Akhirnya pembelajaran antargenerasi menjadi sebuah cara yang efektif untuk mengatasi sejumlah masalah, membangun komunitas yang aktif, mempromosikan kewarganegaraan, memperbaharui lingkungan dan mengatasi ketidaksetaraan. Menyatukan orang-orang dari generasi yang berbeda dalam kegiatan yang bertujuan dan saling menguntungkan, mempromosikan pemahaman dan rasa hormat yang lebih besar antara generasi dan memberikan kontribusi untuk membangun komunitas dan lingkungan di mana orang-orang saling menghormati dan terhubung dengan lebih baik. Membangun sumber daya positif yang ditawarkan oleh generasi muda dan generasi tua dan orang-orang di sekitarnya.

\section{Praktik Pembelajaran Antargenerasi}

Pembelajaran antargenerasi bukan hanya berbicara tentang teknik atau proses pembelajaran; namun ada sesuatu yang lebih di dalamnya. Ini menyangkut bagaimana menyatukan berbagai generasi ke dalam satu proses pembelajaran, tidak peduli apakah mereka generasi yang lebih muda atau lebih tua, dan memungkinkan mereka berbagi, berkomunikasi dan mendiskusikan berbagai ide, perspektif, dan pendapat. Berbeda dari teknik pengajaran dan pembelajaran tradisional lainnya, dalam pembelajaran antargenerasi, baik mentee dan mentor akan belajar sesuatu yang baru dari satu sama lain.

Pendidikan antargenerasi dapat dilakukan melalui banyak cara. Bentuk paling umum yang diambil adalah melalui orang tua yang mengajar atau membimbing pelajar yang lebih muda, orang muda membantu orang tua dalam masalah fisik atau generasi muda dan tua bersama dalam suatu proses pembelajaran. Namun, poin terpenting dari pendidikan antargenerasi adalah bagaimana terlepas dari semua tipe yang berbeda, tidak penting siapa yang seharusnya mengajar siapa; kedua peserta saling belajar sesuatu. Inilah alasan mengapa pembelajaran antargenerasi disebut proses pembelajaran yang saling menguntungkan.

Kita membutuhkan pendidikan atau pembelajaran antargenerasi, berangkat dari apa kesamaan generasi yang berbeda (tujuan, minat, perasaan, sensasi, dan pikiran), menekankan kerja sama, dialog yang empatik, debat dan refleksi. Pendidikan antar generasi membantu untuk meningkatkan pemahaman tentang kehidupan individu dan kehidupan anggota masyarakat lainnya, memberikan kesempatan kepada orang-orang dengan gaya hidup yang berbeda (orang dewasa yang lebih tua, orang dewasa dan pemuda, wanita dan pria, kaya dan miskin, berpendidikan dan kurang terdidik) untuk berpikir dan bertindak bersama, menjadi sumber bimbingan, dukungan dan pemberdayaan. Dalam program ini, para peserta biasanya meningkatkan harga diri dan kepercayaan diri mereka, belajar dan memperoleh perilaku, sikap, nilai dan keterampilan baru, yang membantu mereka mengatasi kondisi kehidupan yang sulit, berkontribusi pada peningkatan kesejahteraan, kepuasan dengan kehidupan, partisipasi sosial, dan istilah-istilah lain dari kualitas hidup.

Kegiatan atau program yang diberi label sebagai pembelajaran antargenerasi perlu memenuhi setidak-tidaknya tiga kriteria berikut, yakni (1) melibatkan lebih dari satu generasi; (2) direncanakan dengan tujuan untuk perubahan (meningkat) dan berkelanjutan, serta saling menguntungkan; (3) mendorong pemahaman dan rasa hormat yang lebih besar di antara generasi, konsekuensinya, dan kohesi komunitas (Kernan \& Cortellesi, 2019, p. 6). Sementara itu, mengutip laman TOY Project, ada enam dimensi kualitas yang perlu ditinjau dan dicvalusi dalam rangka meningkatkan praktik antargenerasi yang melibatkan anak-anak dan orang dewasa yang lebih tua. Yakni, (1) interaksi pada komunitas, (2) inklusi sosial dan kesejahteraan, (3) lingkungan belajar, (4) pengembangan profesional dan tim kerja, (5) pemantauan dan ealuasi, dan (6) keberlanjutan (TOY-PLUS Porject, 2017)

Lebih lanjut, menurut Mannion (2012) teori, kebijakan, dan praktik dalam mendukung pendidikan dan pembelajaran antargenerasi perlu dikembangkan atas dasar pertama, kebutuhan untuk beralih dari melihat input dan output program secara unigenerasional menjadi apresiasi terhadap bagaimana proses pembelajaran dan praktik antargenerasi dialami secara relasional dan timbal balik serta berdampak lintas generasi. Kedua, kebutuan untuk beralih dari melihat pembelajaran antargenerasi dalam keluarga ke pemanfaatan potensi yang belum dimanfaatkan dari tempat-tempat di luar keluarga dari pertemuan antargenerasi sebagai konteks pembelajaran. 
Ketiga, kebutuhan untuk memperluas tujuan program antar generasi; ini tidak hanya menyangkut peningkatan hubungan antar generasi tetapi harus juga mencakup peningkatan kesejahteraan ekososial.

Meninjau beberapa pandangan di atas, penulis berpendapat bahwa dalam merangcang program pembelajaran antargenerasi perlu mengidentifkasi faktor-faktor umum keberhasilan program yang membantu para peserta memeroleh manfaat timbal balik. Di antaranya menetapkan tujuan yang realistis, rencana dan peran yang dapat dicapai serta tanggung jawab yang jelas dari peserta. Selain faktor-faktor umum itu, ada hal-hal praktis yang perlu dipertimbangkan dalam layanan oleh organisasi pengembang pembelajaran antargenerasi, yakni:

1) Tujuan prgram

Prinsip utama dalam merancang pembelajaran antargenerasi adalah memahami betul program yang melibatkan orang muda dan tua. Pertanyaan kuncinya adalah: apakah kegiatan tersebut benar-benar membantu memecahkan hambatan antar generasi?

2) Manfaat timbal balik

Interaksi antara generasi dalam kegiatan pembelajaran perlu diatur sedemikian rupa sehingga menghasilkan pembelajaran yang efektif dan saling menguntungkan. Ini dapat ditempuh dengan mengalokasikan waktu, misalnya beberapa jam per minggu, dan bahkan dapat diperpanjang selama beberapa bulan.

3) Motivasi peserta

Kebutuhan dan motivasi antara orang tua dan kaum muda adalah berbeda-beda. Motivasi orang tua dalam hal meneruskan keterampilan dan pengetahuan, cenderung altruistik. Sementara, kaum muda cenderung terlibat untuk berkontribusi dalam komunitas mereka.

4) Perekrutan peserta

Penyelenggara kegiatan perlu peka terhadap latar belakang orang-orang yang terlibat sebagai peserta, pengalaman dan persepsi sebelumnya, memastikan kerahasiaan dijaga, serta mencari tahu harapan mereka dalam hal keterlibatan mereka dan dukungan yang tersedia.

5) Menyiapkan peserta secara terpisah

Berdiskusi dengan peserta tentang apa yang mereka harapkan dari satu sama lain dan bagaimana mereka berpikir, berperilaku, serta membuat aturan dasar yang jelas tentang bagaimana menghormati pandangan satu sama lain bahkan ketika mereka tidak setuju.

6) Pelibatan tenaga profesional

Setiap orang yang terlibat perlu memahami kegiatan, tidak hanya mereka yang terlibat dalam mengembangkan dan membimbing peran, tetapi juga para staf pendukung vital kegiatan.

7) Daya tarik konten dan pengaturan

Pembelajaran antargenerasi cenderung bekerja paling baik di luar ruang kelas tradisional dan pembelajaran berbasis kelompok, sering berbasis di sekitar proyek tertentu seperti sejarah masyarakat, lingkungan, budaya dan kesenian. Lokasi belajar harus nyaman bahkan bagi orang-orang yang paling sulit untuk terlibat.

8) Lainnya, menyangkut kesulitan kaum muda menyesuaikan kegiatan pembelajaran antargenerasi di sekitar komitmen pendidikan formal mereka serta tentang penerimaan atau penghargaan orang tua atas keandalan (validitas) kompetensi baru mereka. Setiap peserta harus peka dan adaptif terhadap potensi terwujudnya situasi ini.

\section{Simpulan dan Saran}

Dalam masyarakat di mana begitu banyak generasi hidup dan bekerja bersama, diperlukan alat atau kendaraan yang memungkinkan mereka untuk saling memahami, menghormati, dan belajar dari satu sama lain. Pergeseran sistem budaya yang diakibatkan oleh globalisasi, perkembangan teknologi, dan urbanisasi menyebabkan ketegangan dan memperluas kebutuhan akan kohesi sosial. Lebih lanjut, faktor sosial seperti peningkatan usia harapan hidup dan perubahan struktur keluarga dikaitkan dengan terputusnya hubungan antargenerasi, memanggil dunia untuk memberi perhatian dan mengembangkan praktik antargenerasi. Inilah yang kemudian mendorong kita untuk berpikir akan pentingnya pendidikan dan/atau pembelajaran antargenerasi. Pembelajaran antargenerasi merupakan metodologi yang sangat baik untuk 
memungkinkan pendidikan transformatif, dimana setiap orang dapat belajar dari satu sama lain melalui proses seperti pembelajaran observasional, imitasi, dan pemodelan. Ini menunjukkan bahwa pengembangan program antargenerasi menciptakan peluang belajar yang signifikan dan transformasi dalam sikap antargenerasi. Solidaritas antargenerasi dan antarbudaya pun terpupuk. Pembelajaran antargenerasi memungkinkan partisipasi generasi dalam kegiatan yang mempromosikan dialog antargenerasi dan memungkinkan generasi untuk terlibat dalam perolehan keterampilan, nilai, dan pengetahuan. Ini adalah salah satu cara untuk mengatasi perubahan demografis dan memberikan kontribusi penting bagi pengembangan modal sosial dan kohesi sosial dalam masyarakat. Pendidikan antargenerasi dapat dilakukan melalui banyak cara. Akan tetapi, pelaksanaannya berbeda dari teknik pengajaran dan pembelajaran tradisional lainnya. Membutuhkan kriteria tertentu seperti keterlibatan lebih dari satu generasi, bertujuan untuk perubahan, berkelanjutan, dan saling menguntungkan, mendorong pemahaman dan rasa hormat yang lebih besar di antara generasi dan kohesi komunitas.

\section{Daftar Rujukan}

Aemmi, S. Z., \& Moonaghi, H. K. (2017). Intergenerational learning program: A bridge between generations. In International Journal of Pediatrics. https://doi.org/10.22038/ijp.2017.28072.2430

Bencsik, A., Juhász, T., \& Horváth-Csikós, G. (2016). Y and Z Generations at Workplaces. Journal of Competitiveness. https://doi.org/10.7441/joc.2016.03.06

Berčan, M., \& Ovsenik, M. (2019). Intergenerational Learning: A Cornerstone of Quality Aging. Journal of Educational and Social Research, 9(2), 67-71. https://doi.org/10.2478/jesr2019-0014

Berger, P. L., \& Luckmann, T. (1991). The Social Construction of Reality: A Treatise in the Sociology of Knowledge. Penguin Book.

Bossert, P. J. (1999). Book Review: Growing Up Digital: The Rise of the Net Generation. NASSP Bulletin, 83(607), 86-88. https://doi.org/10.1177/019263659908360714

Costanza, D. P., Badger, J. M., Fraser, R. L., Severt, J. B., \& Gade, P. A. (2012). Generational Differences in Work-Related Attitudes: A Meta-analysis. Journal of Business and Psychology, 27(4), 375-394. https://doi.org/10.1007/s10869-012-9259-4

Cotten, S. R., Anderson, W. A., \& McCullough, B. M. (2013). Impact of Internet Use on Loneliness and Contact with Others Among Older Adults: Cross-Sectional Analysis. Journal of Medical Internet Research, 15(2), e39. https://doi.org/10.2196/jmir.2306

Darinskaia, L., \& Moskvicheva, N. (2019). Intergenerational Education As a Resource of Digital Socialization of Older People. Proceedings of the 2019 International Conference on Pedagogy, Communication and Sociology (ICPCS 2019). https://doi.org/10.2991/icpcs-19.2019.99

Dimock, M. (2019). Defining generations: Where Millennials end and Generation $Z$ begins. Pew Research Center. https://www.pewresearch.org/fact-tank/2019/01/17/wheremillennials-end-and-generation-z-begins/

Eckleberry-Hunt, J., \& Tucciarone, J. (2011). The Challenges and Opportunities of Teaching "Generation Y." Journal of Graduate Medical Education. https://doi.org/10.4300/jgme-0304-15

Eurostat. (2019). Population structure and ageing - Statistics Explained. Population Structure and Ageing. $\quad$ https://doi.org/http://ec.europa.eu/eurostat/statisticsexplained/index.php/Population_structure_and_ageing

Finkelstein, L. M., Gonnerman, M. E., \& Foxgrover, S. K. (2001). The Stability of Generation Identification Over Time and Across Contexts. Experimental Aging Research, 27(4), 377397. https://doi.org/10.1080/03610730109342355

Fivush, R., Habermas, T., Waters, T. E. A., \& Zaman, W. (2011). The making of autobiographical memory: Intersections of culture, narratives and identity. International Journal of Psychology, 46(5), 321-345. https://doi.org/10.1080/00207594.2011.596541

Gilbert, C. N., \& Ricketts*, K. G. (2008). Children's Attitudes Toward Older Adults and Aging: A Synthesis of Research. Educational Gerontology, 34(7), 570-586. 
https://doi.org/10.1080/03601270801900420

Glass, A. (2007). Understanding generational differences for competitive success. Industrial and Commercial Training, 39(2), 98-103. https://doi.org/10.1108/00197850710732424

Greenwood, R., Murphy, E., \& Gibson, J. W. (2010). Analyzing Generational Values among Managers and Non-Managers for Sustainable Organizational Effectiveness. SAM Advanced Management Journal, 75(4), 33.

Gursoy, D., Maier, T. A., \& Chi, C. G. (2008). Generational differences: An examination of work values and generational gaps in the hospitality workforce. International Journal of Hospitality Management, 27(3), 448-458. https://doi.org/10.1016/j.ijhm.2007.11.002

Hartman, J. L., \& McCambridge, J. (2011). Optimizing millennials' communication styles. Business Communication Quarterly. https://doi.org/10.1177/1080569910395564

Hartmann, M. (2003). The Web Generation? The (De) Construction of Users, Morals and Consumption. In Technology.

Helsper, E. J., \& Eynon, R. (2010). Digital natives: where is the evidence? British Educational Research Journal, 36(3), 503-520. https://doi.org/10.1080/01411920902989227

Helyer, R., \& Lee, D. (2012). The twenty-first century multiple generation workforce. Education + Training, 54(7), 565-578. https://doi.org/10.1108/00400911211265611

Heng, C. Y., \& Yazdanifard, R. (2013). Generation Gap: Is There a solid solution? From human relation point of view. International Journal of Economy, Management and Social Sciences, 2(10), 837-840.

Henkin, N. Z., \& Butts, D. M. (2012). Intergenerational practice in the United States: past, present and future. Quality in Ageing and Older Adults, 13(4), 249-256. https://doi.org/10.1108/14717791211286913

Howe, N., \& Strauss, W. (2000). Millenials Rising : The Next Generation. Small Business and the City. https://doi.org/10.3138/9781442696501-014

Howe, N., \& Strauss, W. (2007). Millennials go to college: Strategies for a new generation on campus : recruiting and admissions, campus life, and the classroom. LifeCourse Associates.

Imogen Lyons. (2013). Public Perceptions of Older People and Ageing: A Literature Review. Journal of Chemical Information and Modeling, 53(9), 1689-1699. https://doi.org/10.1017/CB09781107415324.004

Joshi, A., Dencker, J. C., \& Franz, G. (2011). Generations in organizations. Research in Organizational Behavior, 31, 177-205. https://doi.org/10.1016/j.riob.2011.10.002

Kaplan, M., Thang, L. L., Sanchez, M., \& Hoffman, J. (2016). Intergenerational Contact Zones A Compendium of Applications. https://aese.psu.edu/extension/intergenerational/articles/intergenerational-contactzones

Kernan, M., \& Cortellesi, G. (Eds.). (2019). Intergenerational Learning in Practice (1st ed.). Routledge. https://doi.org/10.4324/9780429431616

Kornadt, A. E., \& Rothermund, K. (2011). Contexts of aging: Assessing evaluative age stereotypes in different life domains. Journals of Gerontology - Series B Psychological Sciences and Social Sciences. https://doi.org/10.1093/geronb/gbr036

Krippendorff, K. (2004). Content Analysis: An Introduction to Its Methodology (second edition). In SAGE Publications. https://doi.org/10.1103/PhysRevB.31.3460

Kriyantono, R. (2012). Teknik Praktis Riset Komunikasi (6th ed.). Kencana Prenada Media Grup.

Kupperschmidt, B R. (2000). Multigeneration employees: strategies for effective management. The Health Care Manager, 19(1), 65-76. https://doi.org/10.1097/00126450-20001901000011

Kupperschmidt, Betty R. (2006). Addressing multigenerational conflict: Mutual respect and carefronting as strategy. In Online Journal of Issues in Nursing (Vol. 11, Issue 2). https://doi.org/10.1097/01.NOR.0000276979.63173.8d

Liu, W., Pasman, G., Stappers, P. J., \& Taal-Fokker, J. (2012). Making the office catch up: Comparing generation $\mathrm{Y}$ interactions at home and work. Proceedings of the Designing Interactive Systems Conference, DIS '12. https://doi.org/10.1145/2317956.2318061

Lyons, S., \& Kuron, L. (2014). Generational differences in the workplace: A review of the evidence 
and directions for future research. Journal of Organizational Behavior, 35(S1), S139-S157. https://doi.org/10.1002/job.1913

Mannheim, K. (1952). The sociological problem of generation. Essays on the Sociology of Knowledge, 163-195.

Mannheim, K. (1970). The Problem of Generations. Psychoanalytic Review, 57, 378-404.

Mannion, G. (2012). Intergenerational Education: The Significance of Reciprocity and Place. Journal of Intergenerational Relationships, 10(4), 386-399. https://doi.org/10.1080/15350770.2012.726601

Mannion, G. (2018). Intergenerational Education and Learning: We Are in a New Place. In Families, Intergenerationality, and Peer Group Relations (pp. 307-327). Springer Singapore. https://doi.org/10.1007/978-981-287-026-1_5

Meja, V., \& Kettler, D. (2017). The Problem of Generations. In K. H. Wolff (Ed.), From Karl Mannheim (pp. 351-398). Routledge. https://doi.org/10.4324/9780203791318-7

Mendez, N. (2008). Generation Gap. In Loue S.J. \& Sajatovic M. (Eds.), Encyclopedia of Aging and Public Health (pp. 386-387). Springer US. https://doi.org/10.1007/978-0-387-337548_195

Parry, E., \& Urwin, P. (2011). Generational Differences in Work Values: A Review of Theory and Evidence. International Journal of Management Reviews, 13(1), 79-96. https://doi.org/10.1111/j.1468-2370.2010.00285.x

Phillips, J., Ajrouch, K., \& Hillcoat-Nallétamby, S. (2010). Key Concepts in Social Gerontology. SAGE Publications Ltd. https://doi.org/10.4135/9781446251058

Prensky, M. (2001). Digital Natives, Digital Immigrants Part 1. On the Horizon. https://doi.org/10.1108/10748120110424816

Rabušicová, M., \& Novotný, P. (2016). Editorial. Studia Paedagogica, 21(2), 5-8. https://doi.org/10.5817/SP2016-2-1

Reilly, P. (2006). Understanding and Teaching Generation Y. English Teaching Forum, 50(1), 2-11. https://eric.ed.gov/?id=EJ971235

Ropes, D. (2013). Intergenerational learning in organizations. European Journal of Training and Development, 37(8), 713-727. https://doi.org/10.1108/EJTD-11-2012-0081

Rudolph, C. W., Costanza, D. P., Wright, C., \& Zacher, H. (2019). Cross-Temporal Meta-Analysis: A Conceptual and Empirical Critique. Journal of Business and Psychology, 1-18. https://doi.org/10.1007/s10869-019-09659-2

Ryder, N. B. (1965). The Cohort as a Concept in the Study of Social Change. American Sociological Review, 30(6), 843. https://doi.org/10.2307/2090964

Santos, S. R., \& Cox, K. (2000). Workplace adjustment and intergenerational differences between matures, boomers, and xers. Nursing Economic\$, 18(1), 7-13. http://www.ncbi.nlm.nih.gov/pubmed/11029913

Sayers, R. (2007). The right staff from $\mathrm{X}$ to $\mathrm{Y}$. Library Management. https://doi.org/10.1108/01435120710837765

Schuman, H., \& Scott, J. (1989). Generations and Collective Memories. American Sociological Review, 54(3), 359. https://doi.org/10.2307/2095611

Smola, K. W., Sutton, C. D., Wey Smola, K., Sutton, C. D., Smola, K. W., \& Sutton, C. D. (2002). Generational differences: Revisiting generational work values for the new millennium. Journal of Organizational Behavior, 23(4), 363-382. https://doi.org/10.1002/job.147

Stepp, G. (2007). Mind the Gap. Vision Journal, 16(3), 35-41.

Subramanian, K. R. (2017). The Generation Gap and Employee Relationship. International Journal of Engineering and Management Research, 7, 59-67.

Surya Putra Yanuar. (2016). Theoretical Review: Teori Perbedaan Generasi. Among Makarti, 9(18), 123-134. https://jurnal.stieama.ac.id/index.php/ama/article/viewFile/ 142/133

Tari, A. (2011). Z generáció. Budapest: Tericum Kiadó Kft.

Tay, A. (2011). Managing generational diversity at the workplace: expectations and perceptions of different generations of employees. African Journal of Business Management, 5(2), 249255. https://doi.org/10.5897/AJBM10.335

TOY-PLUS Porject. (2017). Six dimensions of quality in Intergenerational Practice for TOY. 
ToyProject.Net. http://www.toyproject.net/news/six-dimensions-of-quality-inintergenerational-practice-for-young-and-old-together/

Turnbull, C. F. (2010). Mom just facebooked me and dad knows how to text: The influences of computer-mediated communication on interpersonal communication and differences through generations. The Elon Journal of Undergraduate Research in Communications.

Twenge, J. M. (2010). A Review of the Empirical Evidence on Generational Differences in Work Attitudes. Journal of Business and Psychology, 25(2), 201-210. https://doi.org/10.1007/s10869-010-9165-6

Urick, M. J., \& Hollensbe, E. C. (2014). Toward an Identity-based Perspective of Generations. In E. Parry (Ed.), Toward an Identity-Based Perspective of Generations (pp. 114-128). Routledge.

Urick, M. J., Hollensbe, E. C., \& Fairhurst, G. T. (2017). Differences in Understanding Generation in the Workforce. Journal of Intergenerational Relationships, 15(3), 221-240. https://doi.org/10.1080/15350770.2017.1329583

Venter, E. (2017). Bridging the communication gap between Generation Y and the Baby Boomer generation. International Journal of Adolescence and Youth, 22(4), 497-507. https://doi.org/10.1080/02673843.2016.1267022

Walmsley, A. L. E. (2011). Closing the Communication Gap. Educational Horizons, 90(1), 25-26. https://doi.org/10.1177/0013175X1109000108

Williams, K., Page, R., Petrosky, A., \& Hernandez, E. (2010). Multi-generational marketing: Descriptions, characteristics, lifestyles, and attitudes. The Journal of Applied Business and Economics, 11(2).

Zabel, K. L., Biermeier-Hanson, B. B. J., Baltes, B. B., Early, B. J., \& Shepard, A. (2017). Generational Differences in Work Ethic: Fact or Fiction? Journal of Business and Psychology, 32(3), 301315. https://doi.org/10.1007/s10869-016-9466-5 